\title{
USING EXTENSIVE READING TO IMPROVE STUDENTS' READING ABILITY
}

\author{
Pham Thi Hoang Ngan*, Mai Thi Thanh Thu, Tran Van Dang \\ Nam Dinh University of Nursing
}

\begin{abstract}
Reading is a source of learning and a source of enjoyment. Especially, in a second foreign language situation, a good reading ability is necessary for those studying English for academic and occupational purposes and many universities'curricula. Many previous studies showed that students devote large amounts of time to reading lessons in order to achieve such competence. Yet despite years of instruction and practice in reading, plenty of students have difficulty in improving their reading ability. Of course, there are a number of possible reasons for this such as the lack of vocabulary, reading fluency and reading habits. There are different ways to improve students' reading ability and one of them is through Extensive Reading. Therefore, this paper aims to show problems students face while learning to read and identify benefits of Extensive Reading on improving students' reading ability.
\end{abstract}

Key words: extensive reading; reading ability; vocabulary; reading fluency; reading habit

Received: 06/5/2019; Revised: 23/5/2019; Approved: 29/5/2019

\section{SỬ DỤNG PHƯƠNG THỨC ĐỌC MỞ RỘNG ĐỂ CẢI THIỆN KHẢ NĂNG ĐỌC CỦA SINH VIÊN}

\author{
Phạm Thị Hoàng Ngân*, Mai Thị Thanh Thu, Trần Văn Đăng \\ Trường Đại học Điều Dương Nam Định
}

\section{TÓM TẮT}

Đọc là một cách để học tập và hưởng thụ. Đặc biệt, trong việc học ngoại ngữ thứ hai, khả năng đọc tốt là cần thiết cho việc học tiếng Anh với mục đích học thuật và mục đích nghề nghiệp cũng như trong nhiều chương trình giảng dạy của các trường đại học. Nhiều nghiên cứu trước đây đã chỉ ra, sinh viên dành nhiều thời gian đối với các bài học đọc để đạt được năng lực như vậy. Mặc dù có nhiều năm được hướng dẫn và thực hành về cách đọc, nhiều sinh viên học tiếng Anh vẫn gặp khó khăn trong việc cải thiện khả năng đọc. Tất nhiên, có một số lý do cho việc này như việc thiếu từ vựng, đọc lưu loát và thói quen đọc. Có nhiều cách khác nhau để cải thiện khả năng đọc của sinh viên và một trong số đó là phương thức “đọc mở rộng”. Do đó, bài báo nhằm mục đích chỉ ra các vấn đề mà sinh viên gặp phải trong khi học đọc và tìm ra lợi ích của việc "đọc mở rộng” đối với việc cải thiện khả năng đọc của sinh viên.

Từ khóa: đọc mở rộng; khả năng đọc; tù̀ vụng; đọc luu loát; thói quen đọc

Ngày nhận bài: 06/5/2019; Ngày hoàn thiện: 23/5/2019; Ngày duyệt đăng: 29/5/2019

* Corresponding author. Email: nganpham200178@ yahoo.com
DOI: $\underline{\text { https://doi.org/10.34238/tnu-jst.2019.06.1130 }}$ 


\section{Introduction}

Reading ability which refers to reading comprehension and speed is very important in our daily life and studies including EFL (English as a Foreign Language) courses. The aim of the syllabus of English for Nurses at Nam Dinh University of Nursing (NDUN) is that students will be able to read specific documents in English after an English course face to face. In fact, this aim seems not to be achieved because many students have difficulties in making sense of texts they want to read at the end of the course and even at their work in the future. The main reasons for their bad reading are: they lack vocabulary, reading fluency and reading habit. Thus, the question most teachers of English often concern about is how they can help their students overcome these problems so that they can improve their reading ability.

Extensive reading has been considered to be an indispensable means of developing students' reading ability [1]. Day and Bamford [2] defined extensive reading in a second language (L2) as "an approach to the teaching and learning of second language reading in which learners read large quantities of books and other materials that are well within their linguistic competence". So far, many researchers such as Horst [3], Pigada \& Schmitt [4] and Soltani [5] etc have provided evidence for the benefits of extensive reading on language learning including reading ability. Therefore, this paper is going to identify some common problems that students have while learning to read and how can extensive reading solve these problems to improve their reading ability.

\section{Problems students usually face while learning to read}

\subsection{The lack of vocabulary}

If reading has been considered to be a significant and viable means of language development for second and foreign language learner by Day and Bamford [2], vocabulary plays an important role in reading. Most second language readers would affirm that their main obstacle to reading is their lack of vocabulary. Wang [6, p. 47] also stated that "Many students probably consider that their main problem in reading is not having enough vocabulary." According to Hsueh-chau and Nation [7], most learners would need to know about $98 \%$ of the words in a text before they are be able to guess the meaning of a word from its context. This seems to be difficult for students because many of them do not have enough vocabulary like that. The results from the study made by a group of authors Mokhtar et al. [8] has shown that the majority of the students are still weak in terms of their English passive and active vocabulary knowledge. Then this lack of vocabulary makes it difficult for them to guess the meanings of words in context and cannot do reading comprehension well. Besides, this is the reason why many students use their dictionaries for the meaning of words so that they feel tired and time consuming. Furthermore, when they look up words in the dictionary, they often feel frustrated and confused by what they find since sometimes meanings in it are very common. In other words, that causes decrease of their reading speed.

\subsection{The lack of reading fluency}

The second problem in reading ability is that students do not have enough reading fluency. According to the National Reading Panel, fluency is reading with speed, accuracy, and expression [9]. Johns and Burglund (2006) extend the definition of fluency, to include the ability to comprehend the material being read [9]. A fluent reader can identify words in the text automatically. Grabe [10] also stated that fluent reading was what most good readers did most of time when they read almost anything either in their L1 or L2 and reading fluency had been associated with reading 
comprehension. From my experience of teaching English, I found that students often read texts without fluency. They read words by words slowly without accuracy and do not understand expressions in the texts. Explaining for this situation, teachers find that reading lessons in textbooks for L2 students do not aim at improving students' reading fluency. They often read texts in silent and do not take care of time or accuracy of reading. Then they try to translate them into L1. Besides, English is usually taught in large classes so teachers do not have enough time to ask each student to read aloud the texts and to give them good feedbacks.

\subsection{The lack of reading habit}

Although many students know that reading everyday seems to be the best way to read well, they still do not have good reading habit, especially in L2. In my previous study on self-study, 478 students at my university were asked "Do you have any books to read more apart from the one you have to use in the course?", 3,5\% of these students answered "Yes". That means most students do not have habits of reading. Students who seldom read had a much lower average score than students who often read.

Explaining for their lack of reading habits, the students said that with a small amount of vocabulary they have, the texts in their books were often difficult for them to understand and sometimes they were not their interesting topics. After reading difficult texts without understanding and enjoyment, they begin to lose motivation and pleasure for reading. In addition to this, at school where English is not the main subject, there are few books, newspapers or magazines in English which are suitable for them to read outside classes. Gradually, they are afraid of reading and cannot create reading habit for themselves.

\section{Extensive reading - one way to deal with the above mentioned problems}

It is probable that the above-mentioned problems are in vicious circle. Students' reading abilities are bad because of lacking vocabulary, frequency and reading habit. It doesn't matter where you enter the problem because any of the problems will produce any of the others. For example, students who do not have enough vocabulary and frequency in reading will do not have reading habit and verse. Thus, it is necessary to solve all the problems at the same time. In fact, there are many ways to improve students' vocabulary, reading fluency and reading habit separately. However, extensive reading is considered to be the best way as it can solve these problems at the same time. Richard and Schmidt (2002) report that extensive reading is tended to develop good reading habits, to build up knowledge of vocabulary and encourage a liking for reading [11].

\subsection{Extensive reading can increase vocabulary}

In fact, not all of words are learnt by being taught, most of them were learnt when students meet them in the context. Usually this involved assimilating the meaning gradually, after frequent encounters. In the classroom, students do not get enough exposure for this natural assimilation to be possible. Therefore, solutions outside should be found. Wang [6] indicates that the most effective way of improving vocabulary is extensive reading.

Regarding Extensive reading, Hafiz and Tudor [12] stated extensive reading is reading a large amount of second language material for pleasure without any task and exercise fulfillment. This approach facilitates students' autonomy and provides them with the opportunity to meet words in their context of used, increases sight vocabulary, and could theoretically result in substantial vocabulary learning, which seems difficult to achieve 
with explicit teaching during the relatively short period of time that L2 learners spend in the language classroom [13]. Besides, extensive reading can also encourage students to gain new vocabulary through reading and thus their vocabulary recognition is built naturally. In the study by Lai (1993) (cited in [13]), the findings showed that there were three experimental groups which displayed better scores in vocabulary recognition compared to the control groups. Furthermore, there is no reason to doubt the finding that students incidentally gain small amounts of vocabulary knowledge from each meaning focused reading an appropriate text and with the characteristic of an Extensive reading approach such as students read as much as possible, that will help students remember their vocabulary for a long time. It is obvious that extensive reading can help students develop vocabulary. Educators and researchers have known that there is a strong correlation relationship between vocabulary development and reading comprehension. The more words students know in the reading texts, the better they comprehend the texts. Moreover, this also helps them improve their reading speed because they can guess the meanings of other new words quickly and do not waste of time looking words up in the dictionary.

\subsection{Extensive reading deals with fluency problem}

A number of researchers indicate that good reading ability is virtually impossible in the absence of reading fluency. Therefore, efficient ways of increasing reading fluency must be found to improve reading ability. According to Day and Bamford [14] Extensive reading promotes reading fluency. As students are asked to read a large amount of comprehensive materials, speed becomes important to facilitate the enjoyment and comprehension of materials. In studies on reading rate, extensive reading has been shown to increase students' reading speed.
Iwahori's study [15] showed that students' reading rates improved after a 7-week extensive reading treatment. The meaning reading rate from the pretest to the posttest improved from 84.18 to 112.82 . Besides, decoding words automatically is needed for reading fluency. Words that students can recognize rapidly accurately and automatically have been called sight vocabulary. Sight vocabulary is essential for improving reading fluency. When students have a great deal of sight vocabulary, they can decode more words automatically. As a result, they can save their finite cognitive resources to comprehend a text. Also, sight vocabulary was proven to be increased by extensive reading above. That means extensive reading can improve students' reading fluency.That means extensive reading can improve students' reading fluency. With specific reference to reading fluency development, extensive reading has shown to be effective in increasing their reading speed and comprehension [16].

\subsection{Extensive reading creates reading habit}

Lacking reading habit is one of students' problems mentioned above. Students do not have interest in reading partly because their vocabulary and reading fluency is not good enough. After these problems are solved by extensive reading, students' are more confident in reading. In other words, extensive reading indirectly improves students' reading ability. Furthermore, to have reading habits students also need to have pleasure and motivation.

Reading for pleasure requires a large selection of books that is available for students to choose and these books should be fit their level. Extensive reading can deal with this because some characteristics of an extensive reading approach from Day and Bamford [14] are: students can read as much as possible inside or outside classrooms; a variety of materials on a 
wide range of topic is available to encourage students to read for different reasons and in different ways; students select what they want to read and have freedom to stop if they are not interested in them; and the purposes of reading are usually related to pleasure.

One of the key factors to make students have reading habits is good attitude and motivation. Day and Bamford [2] reported that positive effects of extensive reading are facilitating growth of student's attitudes toward reading and increasing their motivation to read. Since extensive reading supplies materials that are interesting to the students, they will be far more likely to be stimulated motivation to read. In addition, the findings of previous research prove the effect of extensive reading on learners' attitudes towards reading in the second language. Likewise, with motivation to read and good attitude to reading students will gradually have reading habit everyday. Perhaps this is because the more one reads, the easier reading becomes.

\section{Discussion}

On the whole, extensive reading with its characteristics has helped students overcome their difficulties in learning to read. The reason why extensive reading is considered to be better than the other methods on improving reading ability is that it can solve students' difficulties at the same time. It is very likely that their reading abilities will increase in the long term if this reading is kept up and students are supplied with suitable materials and attention from their teachers.

However, students at NDUN have faced a number of challenges in using Extensive reading including lack of time, shortage of appropriate reading materials. Furthermore, English is taught at the first year while the students have not adapted to new learning environment. They seem to be too busy to have time for reading something apart from their course books. Also, their levels of English are not the same so the teachers find it difficult to provide them the appropriate reading material. Moreover, the reading materials are not available in the library. Therefore, the teachers play crucial roles for the sucessess of the approach. They should introduce the Extensive Reading programme to their students, help students to choose appropriate books, encourge students to read as much as possible, and monitor students' reading as well as reward them if they reach the target number of books.

\section{Conclusion}

In conclusion, this paper has pointed out that students' lack of vocabulary, reading fluency and reading habit are three major problems that students are likely to encounter, which make them entangle in vicious circle of reading, then become bad readers. Although extensive reading is not without problems, it is considered to be able to deal with all these problems which help students improve their reading ability. However, extensive reading is still the missing ingredient in the EFL context of Vietnamese universities. Due to this situation, this paper was written with the hope that teachers and students in Vietnam will have right perception about the role of extensive reading and will apply it on improving students' reading ability.

\section{REFERENCES}

[1]. Sheu, S.P., "The effects of Extensive reading on learners' reading ability development," Journal of National Taipei Teachers College, vol 17, no. 2, pp.213-228, 2004.

[2]. Day, R. R. and Bamford, J., Extensive reading in the second language classroom. Cambridge: Cambridge University Press, 1998.

[3]. Horst, M., "Learning L2 Vocabulary through Extensive Reading: A measurement Study," The Canadian Modern language Review, vol. 61, no. 3, pp. 355-382, 2005.

[4]. Pigada, M. \& Schmitt, N., "Vocabulary acquisition from extensive reading: A case 
study," Reading in a Foreign Language, vol. 18, no. 1, 2006.

[5]. Soltani, R., "Extensive Reading A Stimulant to Improve Vocabulary Knowledge," Studies in literature and Language, vol. 2, no.3, pp. 161-167, 2011.

[6]. Wang, L., "How to improve students' reading ability," US-China education review, vol.3, no.5, pp.47-51, 2006.

[7]. Hsueh-chau, M. H. \& Nation, P., "Unknown vocabulary density and reading comprehension," Reading in a Foreign Language, vol. 13, no. 1, pp.403-430, 2000.

[8]. MohdAsraf, R \& Ahmad, I. S., "Promoting English language development and the reading habit among students in rural schools through the Guided Extensive Reading programme," Reading in a Foreign Language, vol. 15, no. 15, pp.84-102, 2010.

[9]. Dunn, M., "Reading fluency: What, Why, and How?".[Online].Available:http://www.u46.or g/dbs/roadmap/files/.../news-fluency. [Accessed Sept 11, 2010].

[10]. Grabe, W., "Fluency in reading-thirty-five years later," Reading in a Foreign Language, vol. 22, no. 1, pp.71-83, 2010.
[11]. Meng, F., “Developing Students' Reading Ability through Extensive Reading," English Language Teaching, vol. 2, no. 2, pp.132-137, 2009.

[12]. Hafiz, F.M. \& Tudor, I., "Extensive reading and the development of language skills," ETL journal, vol. 34, no. 1, pp. 5-13, 1989.

[13]. Pigada, M. \& Schmitt, N., "Vocabulary acquisition from extensive reading: A case study," Reading in a Foreign Language, vol. 18, no. 1, 2006.

[14]. Day, R. R., \& Bamford, J., "Top ten principles for teaching extensive reading," Reading in a Foreign Language, vol.14, pp.136-141, 2002.

[15]. Iwahori,Y., "Developing reading fluency: A study of extensive reading in EFL," Reading in a Foreign Language, vol. 20, no. 1, pp.7091, 2008.

[16]. Bell, T., "Extensive reading: Speed and comprehension," The Reading Matrix, vol. 1, no. 1, 2001. 